\title{
Differentiation Among Romanian Wine Regions Based on Lead Isotope Signatures
}

\author{
Florin Dumitru BORA ${ }^{1}$, Anamaria CĂLUGĂR ${ }^{2}$, Claudiu Ioan BUNEA ${ }^{2,4^{*}}$, Ionut RACZ ${ }^{3}$ \\ ${ }^{1}$ Department of Physico-Chemistry and Biochemistry, Research Station for Viticulture and Enology \\ Târgu Bujoru, Romania \\ ${ }^{2}$ Department of Horticulture and Landscaping, University of Agricultural Sciences and Veterinary \\ Medicine, Cluj-Napoca, Romania \\ ${ }^{3}$ Wheat Breeding Department, Agricultural Research and Development Station Turda, Cluj-Napoca, \\ Romania \\ ${ }^{4}$ Department of Horticulture and Landscaping, Horticultural Research Station, Cluj-Napoca, Romania. \\ *corresponding author: claus_bunea@yahoo.com
}

BulletinUASVM Horticulture 76(2) / 2019

Print ISSN 1843-5254, Electronic ISSN 1843-5394

DOI:10.15835/buasvmcn-hort: 2019.0007

\begin{abstract}
The objective of this study is to determine the $\mathrm{Pb}$ concentration and ${ }^{206} \mathrm{~Pb} /{ }^{204} \mathrm{~Pb},{ }^{206} \mathrm{~Pb} /{ }^{207} \mathrm{~Pb},{ }^{206} \mathrm{~Pb} /{ }^{208} \mathrm{~Pb}$ from several Romanian winemaking regions, in order to highlight credible geographical markers of wine origin. The $\mathrm{Pb}$ level concentration and the ratios of ${ }^{206} \mathrm{~Pb} /{ }^{204} \mathrm{~Pb},{ }^{206} \mathrm{~Pb} /{ }^{207} \mathrm{~Pb},{ }^{206} \mathrm{~Pb} /{ }^{208} \mathrm{~Pb}$ were determined in 25 white and 9 red wines using ICP-MS techniques. Based on ${ }^{206} \mathrm{~Pb} /{ }^{207} \mathrm{~Pb}$ isotope ratios it can be concluded that the vines grown in the Tîrnave vineyard [Blaj (1.1790 average value)], Huși vineyard [Huși (1.1958 average value wine center), Averești (1.1908 average value)] and Iași vineyard [Copou (1.1875 average value) wine center], show traces of atmospheric pollution with lead [if ${ }^{206} \mathrm{~Pb} /{ }^{207} \mathrm{~Pb}=\sim 1.1700-1.2200$ (atmospheric pollution)]. Combining the ${ }^{206} \mathrm{~Pb} /{ }^{204} \mathrm{~Pb}$ with ${ }^{206} \mathrm{~Pb} /{ }^{208} \mathrm{~Pb}$ isotopic ratio may carry out a separation on the vineyards and wine-growing centers. Based on ${ }^{206} \mathrm{~Pb} /{ }^{204} \mathrm{~Pb},{ }^{206} \mathrm{~Pb} /{ }^{207} \mathrm{~Pb}$ and ${ }^{208} \mathrm{~Pb} /{ }^{206} \mathrm{~Pb}$ a separation of the wine samples was possible.
\end{abstract}

Keywords: geographic origin, isotope ratio, wine fingerprint

\section{Introduction}

Among potentially toxic elements, $\mathrm{Pb}$ is possibly the most widely emitted by anthropogenic activities due to a long history of its utilization by mankind. The earliest known $\mathrm{Pb}$ artefact dates to $5600 \mathrm{BCE}$, and the processing to $\mathrm{Pb}$ minerals improved significantly about 6000 years ago (Nriagu, 1983). At present, $\mathrm{Pb}$ pollution has been reported world-wide (Martín et al., 2014, Liu et al., 2016). Lead contamination of soil poses potential health risks to humans via the food chain. Lead poisoning in adults can affect the nervous system, immune system, cardiovascular system and reproductive system (Needleman, 2004). Children are more susceptible to $\mathrm{Pb}$ than adults when exposed to $\mathrm{Pb}$, which causes neuropsychological abnormalities and impaired learning abilities (Chiodo et al., 2007). Therefore, prevention and control of $\mathrm{Pb}$ pollution are important environmental concerns (Liu et al., 2019).

Source apportionment is necessary to determine control strategies to reduce $\mathrm{Pb}$ pollution and limit human exposure. Unravelling the relative contributions of $\mathrm{Pb}$ derived from different sources 
is the prerequisite for remediation (Morrison, 2000). Furthermore, information on source apportionment can help choose the appropriate remediation strategies. However, in most cases, the sources of $\mathrm{Pb}$ are complex, for example, soil $\mathrm{Pb}$ can originate from multiple sources and pathways, such as atmospheric deposition, irrigation, leaded pesticides, irrigation, and atmospheric deposition. The complexity of potential sources and the uncertainty of interactions among soil, water, air, and organisms may increase the difficulty of $\mathrm{Pb}$ source apportionment (Liu et al., 2019).

The presence of $\mathrm{Pb}$ in wine is associated with two major sources as follows: human activity which results from the use of fertilizers, pesticides and agriculture, food additives, environmental pollution and natural sources which are due to the weathering of rocks (Almeida et al., 2016).

In nature, there are three radioactive decay series, ${ }^{232} \mathrm{Th},{ }^{238} \mathrm{U}$ and ${ }^{235} \mathrm{U}$. The parent element is a long-lived radioactive element and the last member of the series is a stable $\mathrm{Pb}$ isotope such as ${ }^{206} \mathrm{~Pb},{ }^{207} \mathrm{~Pb}$ or ${ }^{208} \mathrm{~Pb}$ and is known as a radiogenic lead isotope. The stable $\mathrm{Pb}$ isotope, ${ }^{204} \mathrm{~Pb}$, is nonradiogenic. The $\mathrm{Pb}$ isotope ratio depends on factors such as $U$ and Th content in the soil, weathering processes and original rock age, which provide a fingerprint used for different forensic and archeological purposes (Mihaljevič et al., 2006).

The present study aimed to determine the $\mathrm{Pb}$ concentration and ${ }^{206} \mathrm{~Pb} /{ }^{204} \mathrm{~Pb},{ }^{206} \mathrm{~Pb} /{ }^{207} \mathrm{~Pb}$, ${ }^{206} \mathrm{~Pb} /{ }^{208} \mathrm{~Pb}$ isotopic ratio from 25 white and 9 red wines using ICP-MS technique, in order to highlight credible geographical markers of wine origin. Wine samples were obtained under microvinification conditions of native and international varieties of vine.

\section{Materials and methods}

The samples used in this experiment were obtained from wines produced from Feteasca alba, Pinot gris, Sauvignon blanc, Feteasca regala, Italian Riesling, Muscat Ottonel, Feteasca neagra, Cabernet Sauvignon, Babeasca neagra, Sarba, Aligoté, Merlot and Busuioaca de Bohotin, under conditions of 2013-2017 from Tîrnave, Dealu Bujorului, Huși and Iași vineyards. The vineyards region is characterized by an alternate landscape, from flat to hilly areas, with altitude between 100 and $225 \mathrm{~m}$ and the predominant soil is levigated chernozem having a clayey sand texture with $\mathrm{pH}$ between values 7.4 and 8.1. Although they have moisture deficit, natural conditions (ecoclimatic and ecopedological) offer viable ecosystem for the development of vineyard. The wine samples were produced in micro-vinification conditions according to the methodology described by Bora et al. (2018). All vines were planted since 1979, and the vine plantation was organized with $2.2 \times$ $1 \mathrm{~m}$ distance between rows and plants. Vines were pruned according to the Guyot system and were grown on speliers.

For the determination of $\mathrm{Pb}$ from wine samples were used in amount of $0.5 \mathrm{~mL}$ wine and adjust $8 \mathrm{~mL}\left(7 \mathrm{~mL}\right.$ of $65 \% \mathrm{HNO}_{3}+1 \mathrm{ml}$ of $35 \%$ $\mathrm{H}_{2} \mathrm{O}_{2}$ ), after 15-45 minutes the mineralization was performed using Milestone START D Digestion System a microwave system. After mineralization process, wine samples were filtered through a 45.0 $\mathrm{mm}$ filter and brought to a volume of $50 \mathrm{ml}$. The method of microwave digestion was optimized in a previous work (Bora et al., 2018).

The analysis was made using ICP-MS (iCAP Q Thermo Scientific) technique, after an appropriate dilution, using external standard calibration methods. The determination of $\mathrm{Pb}$ concentration and isotope ratio from wine was optimized in a previouswork(Bora etal., 2018).Isotopic reference materials of $\mathrm{Pb}$ (NIST SRM 981) from National Institute for Standards and Technology (NIST, Gaithersburg, MD, USA), were used for correction of the mass bias induced by instrumental mass discrimination. For determination of $\mathrm{Pb}$ in wine, calibration was performed using XXICertiPUR multielement standard.

For calibration and also to verify the achieved accuracy and precision, ten NIST-SRM 981 analysis results were pooled together with the calculated relative standard deviation presented in Table 1. Based on the obtained results, it was verified that applying quadrupole ICP-MS, relative standard deviation and reproducibility of approximately $0.5 \%$ for ${ }^{87} \mathrm{Sr} /{ }^{86} \mathrm{Sr},{ }^{206} \mathrm{~Pb} /{ }^{207} \mathrm{~Pb}$ and ${ }^{208} \mathrm{~Pb} /{ }^{206} \mathrm{~Pb}$ are feasible.

\section{Results and discussions}

$\mathrm{The} \mathrm{Pb}$ concentration in the analysed wines corresponds to levels reported from neighboring countries and generally from the literature and in all exanimated samples was below the maximum admissible limit established by International Organization of Vine and Wine (O.I.V) reglemen- 
Table 1. Lead isotopic ratio and Lead isotopic ratio determination precision and accuracy based on the NIST SRM 981 (Lead) $(\mathrm{n}=10)$

\begin{tabular}{ccccccc}
\hline Replicate & ${ }^{207} \mathrm{~Pb} /{ }^{206} \mathrm{~Pb}(\mathrm{a})$ & $\mathrm{RSD}(\%)$ & ${ }^{208} \mathrm{~Pb} /{ }^{206} \mathrm{~Pb}(\mathrm{~b})$ & $\mathrm{RSD}(\%)$ & ${ }^{204} \mathrm{~Pb} /{ }^{206} \mathrm{~Pb}(\mathrm{c})$ & $\mathrm{RSD}(\%)$ \\
\hline 1 & 0.46483 & 0.51 & 0.99891 & 0.67 & 0.00271 & 0.32 \\
\hline 2 & 0.47891 & 0.48 & 0.99452 & 0.61 & 0.00272 & 0.41 \\
\hline 3 & 0.46978 & 0.32 & 0.99794 & 0.55 & 0.00275 & 0.28 \\
\hline 4 & 0.47123 & 0.64 & 0.99688 & 0.64 & 0.00273 & 0.51 \\
\hline 5 & 0.46987 & 0.56 & 0.99726 & 0.48 & 0.00246 & 0.14 \\
\hline 6 & 0.46154 & 0.37 & 0.99647 & 0.56 & 0.00258 & 0.39 \\
\hline 7 & 0.47362 & 0.70 & 0.99969 & 0.34 & 0.00279 & 0.47 \\
\hline 8 & 0.45641 & 0.43 & 0.99744 & 0.58 & 0.00278 & 0.51 \\
\hline 10 & 0.41562 & 0.36 & 0.99576 & 0.59 & 0.00273 & 0.49 \\
\hline Average & 0.45612 & 0.45 & 0.99874 & 0.61 & 0.00278 & 0.36 \\
\hline
\end{tabular}

(a) Certified value $={ }^{207} \mathrm{~Pb} /{ }^{206} \mathrm{~Pb}(0.46707 \pm 0.00020)$; (b) Certified value $={ }^{208} \mathrm{~Pb} /{ }^{206} \mathrm{~Pb}(1.00016 \pm 0.00036)$;

(c) Certified value $={ }^{204} \mathrm{~Pb} /{ }^{206} \mathrm{~Pb}(0.027219 \pm 0.00027) ; \mathrm{RSD}(\%)=$ relative standard deviation.

tation (150 $\mu \mathrm{g} / \mathrm{L}) \quad$ (O.I.V. 2016). However, significant differences can be observed among the values acquired for $\mathrm{Pb}$ in wines from Dealu Bujorului vineyard $(70.61 \mu \mathrm{g} / \mathrm{L})$, Huși vineyard $(68.36 \mu \mathrm{g} / \mathrm{L})$ and Averești wine center $(66.64$ $\mu \mathrm{g} / \mathrm{L})$, comparing to wines from Iași $(48.96 \mu \mathrm{g} / \mathrm{L})$ and Tîrnave $(49.16 \mu \mathrm{g} / \mathrm{L})$ vineyard. Early studies in England have reported $\mathrm{Pb}$ concentration as high as $1840 \mu \mathrm{g} / \mathrm{L}$ resulting from lad couldrons (Alkiș et al., 2014). As stainless-steel boilers are used presently this problem has seemed to disappear.

The ${ }^{206} \mathrm{~Pb} /{ }^{207} \mathrm{~Pb}$ and ${ }^{206} \mathrm{~Pb} /{ }^{208} \mathrm{~Pb}$ ratios are commonly used as traces to differentiate natural and anthropogenic lead. In central Europe, the lead isotopic ratios, as signatures of pollution sources, ranges from relatively high ${ }^{206} \mathrm{~Pb} /{ }^{207} \mathrm{~Pb}$ ratios (fly ashes, coals and natural $\mathrm{Pb},{ }^{206} \mathrm{~Pb} /{ }^{207} \mathrm{~Pb}$ $=\sim 1.1700$ to 1.2200 ) to low ${ }^{206} \mathrm{~Pb} /{ }^{207} \mathrm{~Pb}$ values (petrol, gasoline, combustion, ${ }^{206} \mathrm{~Pb} /{ }^{207} \mathrm{~Pb}=\sim$ 1.0600 to 1.1400 ) (Avram et al., 2014, Mihaljevič et al., 2006, Bora et al., 2018).

The values of ${ }^{206} \mathrm{~Pb} /{ }^{204} \mathrm{~Pb}$ and ${ }^{206} \mathrm{~Pb} /{ }^{208} \mathrm{~Pb}$ isotope ratios range from 16.3035 to 18.0325 $\left({ }^{206} \mathrm{~Pb} /{ }^{204} \mathrm{~Pb}\right)$ and 1.1950 to $2.3381\left({ }^{206} \mathrm{~Pb} /{ }^{208} \mathrm{~Pb}\right)$. The highest values of ${ }^{206} \mathrm{~Pb} /{ }^{204} \mathrm{~Pb}$ were registered in vine varieties grown in Tîrnave vineyard followed by vine cultivated in the vineyard of Dealu Bujorului. In ${ }^{206} \mathrm{~Pb} /{ }^{208} \mathrm{~Pb}$ the highest values were register to vine varieties grown in Tîrnave vineyard, while in the vine grown in Huși was recorded the lowest isotope ratio. The values of ${ }^{206} \mathrm{~Pb} /{ }^{204} \mathrm{~Pb}$ and ${ }^{206} \mathrm{~Pb} /{ }^{208} \mathrm{~Pb}$ isotope ratio obtained are comparable with Almedida et al. (2016) (2.0700 to 2.1570 Brazilian wines ${ }^{206} \mathrm{~Pb} /{ }^{208} \mathrm{~Pb}$,
16.6670 to 17.9960 Brazilian wines $\left.{ }^{206} \mathrm{~Pb} /{ }^{204} \mathrm{~Pb}\right)$ and also with Barbaste et al. (2001) (2.0990 to 2.1030 Italian wines ${ }^{206} \mathrm{~Pb} /{ }^{208} \mathrm{~Pb}, 17.3210$ Italian wines ${ }^{206} \mathrm{~Pb} /{ }^{204} \mathrm{~Pb}$ ).

Regarding ${ }^{206} \mathrm{~Pb} /{ }^{207} \mathrm{~Pb}$ isotope ratios based on our analyses it can be concluded that the vines grown in the Tîrnave vineyard [Blaj (1.1790 average value) wine center], Huși vineyard (1.1958 average value), Averești wine center (1.1908 average value) and Iași vineyard [Copou (1.1875 average value) wine center], the values of isotopic ratio of these varieties of vine show traces of atmospheric pollution with lead on vine (if ${ }^{206} \mathrm{~Pb} /{ }^{207} \mathrm{~Pb}=\sim 1.1700-1.2200$ [atmospheric pollution]) (Tab. 2). The values of ${ }^{206} \mathrm{~Pb} /{ }^{207} \mathrm{~Pb}$ isotope ratios range between 1.1282 to 1.2642 , values comparable with Avram et al. (2014) and Bora et al. (2018) ( 1.1000 to 1.2000 Romanian wines). Regarding varieties of vine grown in Jidvei (1.1673) and Bujoru wine center (1.1557), the values of isotopic ratio of these vine varieties show traces indigenous lead ores (if ${ }^{206} \mathrm{~Pb} /{ }^{207} \mathrm{~Pb}=\sim$ 1.1500-1.1600 [indigenous lead ores]) (Lichfouse et al., 2013).

The two-dimensional graphs (Fig. 1 and 2) and show that it is possible to differentiate even among the vineyards (Tîrnave, Dealu Bujorului, Huși and Iași) or wine centers (Blaj, Jidvei, Bujoru, Huși, Averești and Copou) based on the ${ }^{208} \mathrm{~Pb} /{ }^{206} \mathrm{~Pb}$ and ${ }^{206} \mathrm{~Pb} /{ }^{204} \mathrm{~Pb}$ isotopic ratios.

Combining the ${ }^{206} \mathrm{~Pb} /{ }^{204} \mathrm{~Pb}$ with ${ }^{206} \mathrm{~Pb} /{ }^{208} \mathrm{~Pb}$ isotopic ratio may carry out a separation on the samples of wine analyzed on the basis of these isotopic ratios. Wines were grouped in their 
Table 2. The content of $\mathrm{Pb}(\mu \mathrm{g} \mathrm{L}-1)$ and ${ }^{206} \mathrm{~Pb} /{ }^{204} \mathrm{~Pb},{ }^{206} \mathrm{~Pb} /{ }^{207} \mathrm{~Pb}$ and ${ }^{206} \mathrm{~Pb} /{ }^{208} \mathrm{~Pb}$ from wine samples

\begin{tabular}{|c|c|c|c|c|c|c|c|c|}
\hline Vine & $\begin{array}{l}\text { Wine } \\
\text { Center }\end{array}$ & Variety & $\begin{array}{c}\mathrm{Pb} \\
\mu \mathrm{g} \mathrm{L} \mathrm{L}^{-1} \pm \mathrm{SD} \\
\text { (M.L.A. } 150 \mu \mathrm{g} / \mathrm{L} \text { ) }\end{array}$ & ${ }^{206} \mathrm{~Pb} /{ }^{204} \mathrm{~Pb}$ & $\begin{array}{l}\text { RSD / } 206 \mathrm{~Pb} \\
\%\end{array}$ & RSD / & ${ }^{206} \mathrm{~Pb} /{ }^{2}$ & $\begin{array}{c}\text { RSD / } \\
\%\end{array}$ \\
\hline \multirow[t]{11}{*}{ Tîrnave } & Blaj & Feteasca alba & $30.52 \pm 2.11^{\mathrm{kl} \gamma}$ & $16.8883^{\text {de } \alpha}$ & $\begin{array}{ll}0.7 & 1.1703^{\text {bc } \alpha}\end{array}$ & 0.1 & $2.2448^{\text {abcdefg } \alpha}$ & 0.1 \\
\hline & & Pinot gris & $46.06 \pm 8.40 \operatorname{defgh} \alpha$ & $16.7396^{\operatorname{defg} \alpha}$ & $\begin{array}{ll}0.5 & 1.1956^{\mathrm{abc} \alpha}\end{array}$ & 0.1 & $2.2453^{\operatorname{abcdefg} \alpha}$ & 0.9 \\
\hline & & Sauvignon blanc & $20.18 \pm 4.43^{\mathrm{mn} \delta}$ & 16.5684 efgh $\alpha^{-1}$ & $0.5 \quad 1.1812^{\text {bc } \alpha}$ & 0.9 & 2.2392 & 1.8 \\
\hline & & Feteasca regala & $35.86 \pm 5.27^{\mathrm{ijk} \beta \gamma}$ & $16.4355^{\text {gh } \alpha}$ & $0.2 \quad 1.1938^{\mathrm{abc} \alpha}$ & 0.5 & $2.3036^{\mathrm{ab} \alpha}$ & 0.7 \\
\hline & & Italian Riesling & $20.72 \pm 1.80^{\mathrm{mn} \delta}$ & $16.7347^{\operatorname{defg} \alpha}$ & $0.3 \quad 1.1992^{\text {abc } \alpha}$ & 1.3 & $2.3381^{\mathrm{a} \alpha}$ & 0.3 \\
\hline & & Muscat Ottonel & $42.89 \pm 5.588^{\text {efghi } \alpha \beta}$ & $16.8200^{\operatorname{def} \alpha}$ & $0.1 \quad 1.1638^{\text {bc } \alpha}$ & 0.8 & $2.3103^{\mathrm{ab} \alpha}$ & 05 \\
\hline & Jidvei & Feteasca alba & $32.33 \pm 5.90^{\mathrm{jkl} \beta}$ & $16.5649^{\text {efgh } \alpha}$ & $0.5 \quad 1.1712^{\text {bc } \alpha}$ & 0.6 & $2.2575^{\text {abcdef } \alpha}$ & 0.6 \\
\hline & & Pinot gris & $46.09 \pm 5.96^{\operatorname{defgh} \alpha}$ & $16.4267^{\text {gh } \alpha}$ & $\begin{array}{ll}0.8 & 1.1648^{\text {bc } \alpha}\end{array}$ & 0.4 & $2.2980^{a b c \alpha}$ & 0.1 \\
\hline & & Sauvignon blanc & $21.01 \pm 1.28^{\mathrm{mn} \gamma}$ & $16.4675^{\operatorname{fgh} \alpha}$ & $0.4 \quad 1.1555 \mathrm{bc}^{\alpha}$ & 0.1 & $2.2846^{\mathrm{abcd} \alpha}$ & 0.4 \\
\hline & & Feteasca regala & $49.16 \pm 2.65^{\operatorname{defg} \alpha}$ & $16.3035^{\mathrm{h} \alpha}$ & $\begin{array}{ll}0.2 & 1.1688^{\text {bc } \alpha}\end{array}$ & 1.3 & 2.2673 abcde $\alpha$ & 0.7 \\
\hline & & Muscat Ottonel & $42.54 \pm 1.37^{\text {fghi } \alpha}$ & $16.4344 \operatorname{sh} \alpha^{\mathrm{gh}}$ & $0.8 \quad 1.1762^{\text {bc } \alpha}$ & 0.8 & 2.2339 abcdefg $\alpha$ & 1.6 \\
\hline \multirow[t]{7}{*}{$\begin{array}{c}\text { Dealu } \\
\text { Bujorului } \\
\end{array}$} & Bujoru & Feteasca alba & $23.56 \pm 2.62^{\operatorname{lm} \delta}$ & $16.6558^{\text {efgh } \alpha \beta}$ & $0.3 \quad 1.1337^{\text {bc } \beta}$ & 1.9 & $2.1251^{\text {fghijk } \alpha}$ & 0.1 \\
\hline & & Fetea: & $24.30 \pm 1.22^{\operatorname{lm} \delta}$ & $16.6295^{\text {efgh } \alpha \beta}$ & 1.1352 bc $\beta$ & 0.3 & $2.1661^{\circ}$ & 0.8 \\
\hline & & Feteas & $70.61 \pm 7.37^{\mathrm{a} \alpha}$ & $16.6194^{\text {efgh } \alpha \beta}$ & $1.1347^{\text {bc } \beta}$ & 0.6 & 2.153 & 0.6 \\
\hline & & $\begin{array}{c}\text { Cabernet } \\
\text { Sauvignon }\end{array}$ & 5 & $\alpha \beta$ & 0.2 & 2.5 & 2. & 0.4 \\
\hline & & Babeasca neagra & $38.69 \pm 3.09^{\text {hijk } \gamma}$ & $16.6637^{\text {efgh } \alpha \beta}$ & $1.1282^{\mathrm{c} \beta}$ & 1.2 & $2.1871^{\text {bcdefghi } \alpha}$ & 0.2 \\
\hline & & Sarba & $53.30 \pm 8.36^{\operatorname{cd} \beta}$ & $16.5457^{e^{\operatorname{efgh} \beta}}$ & $1.2642^{\mathrm{a} \alpha}$ & 0.3 & $2.1489^{\text {efghijk } \alpha}$ & 0.7 \\
\hline & & Muscat Ottonel & $13.88 \pm 3.20^{\mathrm{n} \varepsilon}$ & $16.7160^{\operatorname{defg} \alpha}$ & $\begin{array}{ll}0.7 & 1.15633^{\text {bc } \beta}\end{array}$ & 0.6 & $2.1858^{\text {bcdefghi } \alpha}$ & 0.5 \\
\hline \multirow[t]{13}{*}{ Huși } & Huși & Aligoté & $68.36 \pm 4.19$ ab $\alpha$ & $17.3225^{\text {bc } \alpha \beta}$ & $0.4 \quad 1.2010^{a b c \alpha \beta}$ & 0.5 & $2.0198 \mathrm{k} \beta$ & 0.3 \\
\hline & & Feteasca regala & $47.56 \pm 3.27$ defgh $\beta$ & $17.3989^{\mathrm{b} \alpha}$ & $\begin{array}{ll}0.7 & 1.2097^{\mathrm{ab} \alpha} \\
\end{array}$ & 0.9 & $2.0417^{\mathrm{jk} \beta}$ & 0.9 \\
\hline & & Feteasca alba & $30.20 \pm 1.75^{\mathrm{kl} \delta \varepsilon}$ & $17.3556^{\text {bc } \alpha}$ & $1.31 .2013^{\mathrm{abc} \alpha \beta}$ & 0.1 & $2.0625^{\mathrm{ijk} \beta}$ & 0.2 \\
\hline & & Italian Riesling & $35.57 \pm 5.48^{\mathrm{ijk} \gamma \delta}$ & 17.3231 bc $\alpha \beta$ & $0.51 .1988^{a b c \alpha \beta}$ & 0.2 & $2.0531^{\mathrm{ijk} \beta}$ & 0.1 \\
\hline & & Babeasca neagra & $52.08 \pm 2.74^{\text {cde } \beta}$ & $17.4117^{\mathrm{b} \alpha}$ & $\begin{array}{ll}0.4 & 1.2114^{\mathrm{ab} \alpha} \\
\end{array}$ & 0.5 & 2.0797 hijk $\alpha \beta$ & 0.5 \\
\hline & & Feteasca neagra & $38.97 \pm 2.56^{\text {hijk } \gamma}$ & $17.3567^{\mathrm{bc} \alpha}$ & $1.91 .1994^{a b c} \alpha \beta$ & 0.3 & $2.0813^{\text {hijk } \alpha \beta}$ & 0.9 \\
\hline & & $\begin{array}{c}\text { Cabernet } \\
\text { Sauvignon }\end{array}$ & 4 & $17.4959^{\mathrm{b} \alpha}$ & $0.21 .1935^{\mathrm{abc} \alpha \beta}$ & 0.2 & $2.0632^{\mathrm{ijk} \beta}$ & 0.6 \\
\hline & & Merlot & $25.11 \pm 1.22$ & 17.03 & $\begin{array}{ll}0.5 & 1.17 \\
\end{array}$ & 0.6 & $2.11 \varepsilon$ & 0.8 \\
\hline & & $\begin{array}{c}\text { Busuioaca de } \\
\text { Bohotin }\end{array}$ & $52.19 \pm 0.95^{\operatorname{cde} \beta}$ & $17.4185^{b \alpha}$ & 1.1709 bc $\beta$ & 0.7 & 2.2007 bcdefgh $\alpha$ & 0.6 \\
\hline & Averești & Feteasca alba & $66.64 \pm 4.28 \mathrm{ab} \alpha$ & $17.3667^{\text {bc } \alpha}$ & $0.9 \quad 1.1869^{\text {bc } \alpha}$ & 2.8 & $2.0953^{\text {hijk } \alpha}$ & 0.1 \\
\hline & & Feteasca regala & $51.46 \pm 3.61^{\text {cdef } \beta}$ & $17.5741^{\mathrm{b} \alpha}$ & $0.6 \quad 1.1810^{\text {bc } \alpha}$ & 0.3 & $2.0907^{\text {hijk } \alpha}$ & 0.2 \\
\hline & & Feteasca neagra & $60.32 \pm 4.21^{\text {bc } \alpha \beta}$ & $17.4140^{\mathrm{b} \alpha}$ & $1.6 \quad 1.2003^{\mathrm{abc} \alpha}$ & 0.3 & $2.0673^{\text {hijk } \beta}$ & 0.2 \\
\hline & & Merlot & $65.06 \pm 6.33^{\mathrm{ab} \alpha}$ & $17.42696^{\mathrm{b} \alpha}$ & $0.2 \quad 1.1950^{\text {abc } \alpha}$ & 0.1 & 1.1950 bcdefgh $\alpha$ & 0.6 \\
\hline \multirow[t]{3}{*}{ Iași } & Copou & Feteasca regala & $48.96 \pm 11.77^{\operatorname{defg} \alpha}$ & $18.0652^{\text {a } \alpha}$ & $0.6 \quad 1.1759^{\text {bc } \alpha}$ & 0.8 & $2.1673^{\text {cdefghij } \alpha}$ & 0.2 \\
\hline & & Feteasca alba & $40.10 \pm 3.51^{\text {ghij } \alpha}$ & $18.0252^{\mathrm{a} \alpha}$ & $0.9 \quad 1.1943^{\text {abc } \alpha}$ & 0.5 & $2.1286^{\text {fghijk } \alpha}$ & 0.1 \\
\hline & & Italian Riesling & $48.33 \pm 6.95^{\operatorname{defg} \alpha}$ & $18.0325^{\mathrm{a} \alpha}$ & $0.8 \quad 1.1925^{\mathrm{abc} \alpha}$ & 0.2 & $2.1455^{\text {efghijk } \alpha}$ & 0.5 \\
\hline
\end{tabular}

Average value \pm standard deviation $(n=3)$. Roman letters represent the significance of grape varieties cultivated in different wine center (Duncan test, $\mathrm{p}<0.05$ ). Greek letters represent the significance of grape varieties cultivated in the same wine center (Duncan test, $p<0.05$ ). The difference between any two values, followed by at least one common leter, is insignificant. M.P.L = maximul permissible allowed (O.I.V., 2016). $\mathrm{LOQ}=$ lower that the limit of quantification.

distinct groups corresponding to vineyard of provenance (Fig. 3).

Variation of ${ }^{206} \mathrm{~Pb} /{ }^{204} \mathrm{~Pb}, \quad{ }^{206} \mathrm{~Pb} /{ }^{207} \mathrm{~Pb}$ and ${ }^{208} \mathrm{~Pb} /{ }^{206} \mathrm{~Pb}$ in wines with different geographical origins confirm the link with geological substratum of the production territory, making the ${ }^{206} \mathrm{~Pb} /{ }^{204} \mathrm{~Pb}$, ${ }^{206} \mathrm{~Pb} /{ }^{207} \mathrm{~Pb}$ and ${ }^{206} \mathrm{~Pb} /{ }^{208} \mathrm{~Pb}$ a robust instrument for tracing the geographical provenance of wines. 


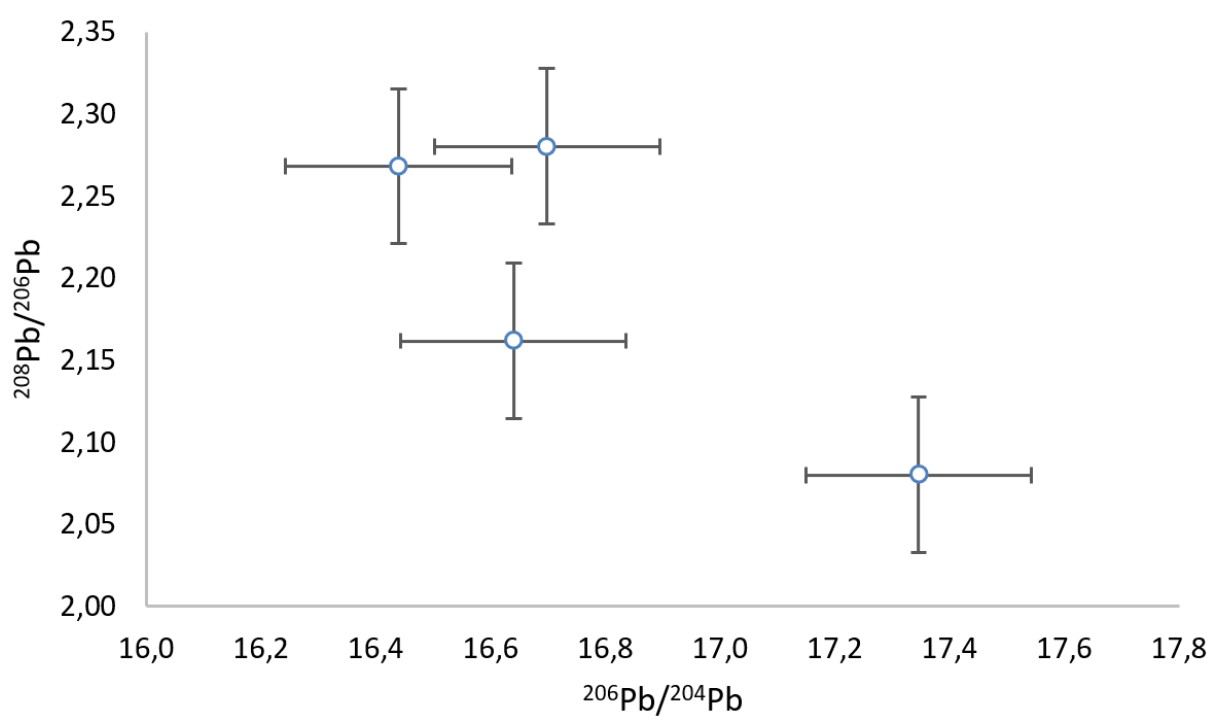

Figure 1. Distributions of wine samples based on the isotopic ratios of the vineyard area

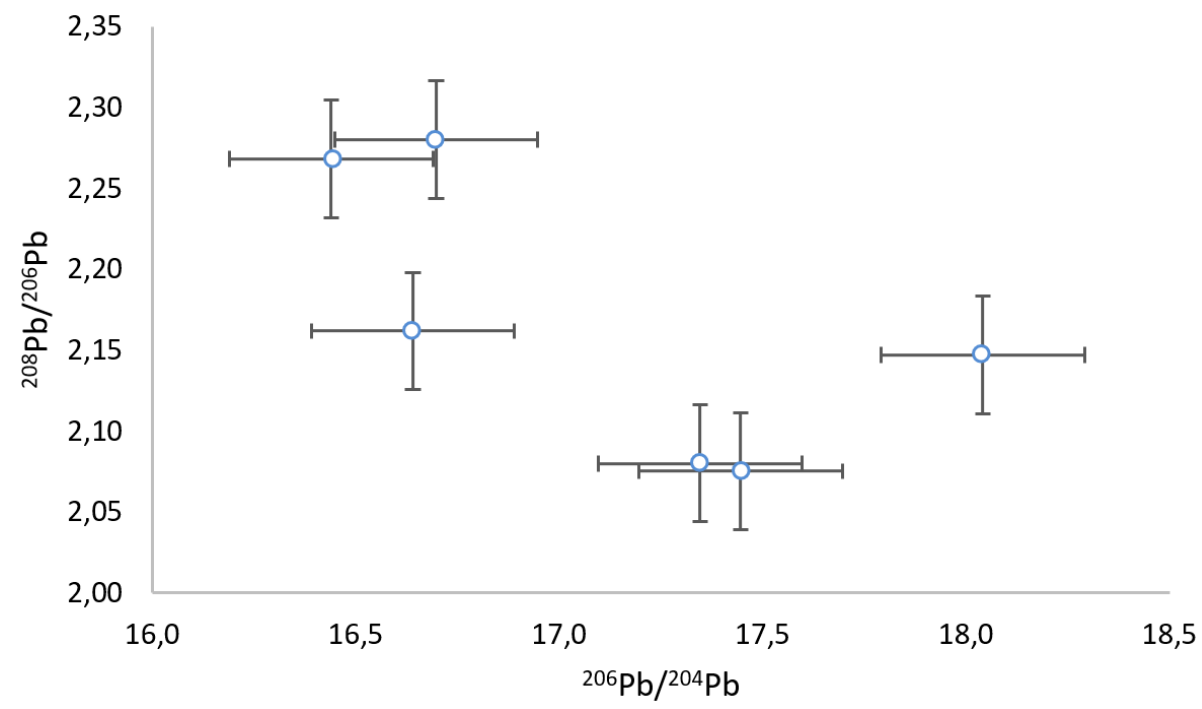

Figure 2. Distributions of wine samples based on the isotopic ratios of the wine center area

\section{Conclusion}

$\mathrm{Pb}$ concentration found in wine from four vineyards studied did not vary greatly and was well below the limits established by Organization of Vine and Wine. However, significant differences can be observed among the values acquired for $\mathrm{Pb}$ in wines from Dealu Bujorului and Huși, comparing to wines from Iași and Tîrnave vineyards. Studies involving isotopic ratios of lead have shown promise in differentiating the wine producing regions of Romania. Regarding ${ }^{206} \mathrm{~Pb} /{ }^{207} \mathrm{~Pb}$ isotope ratios based on analyses it can be concluded that the vines grown in the Tîrnave vineyard [Blaj wine center (1.1790 average value)], Huși vineyard [Huși (1.1958 average value), Averești wine center (1.1908 average value)] and Iași vineyard [Copou wine center (1.1875 average value)], the values of isotopic ratio of these varieties of vine show traces of atmospheric pollution with lead on vine (if ${ }^{206} \mathrm{~Pb} /{ }^{207} \mathrm{~Pb}=\sim 1.1700-1.2200$ [atmospheric pollution]). Combining the ${ }^{206} \mathrm{~Pb} /{ }^{204} \mathrm{~Pb}$ with ${ }^{206} \mathrm{~Pb} /{ }^{208} \mathrm{~Pb}$ isotopic ratio may carry out a separation on the vineyards and wine-growing centers. Based on ${ }^{206} \mathrm{~Pb} /{ }^{204} \mathrm{~Pb},{ }^{206} \mathrm{~Pb} /{ }^{207} \mathrm{~Pb}$ and ${ }^{208} \mathrm{~Pb} /{ }^{206} \mathrm{~Pb}$ a separation of the wine samples was possible. 


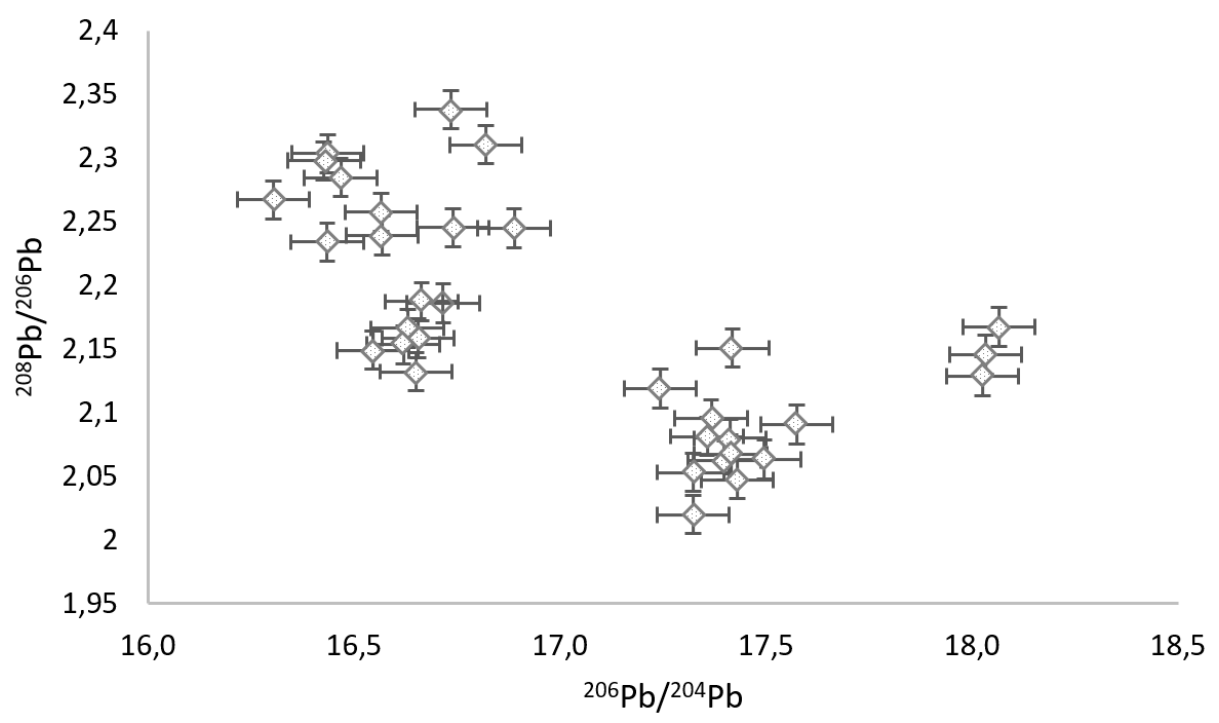

Figure 3. Distributions of wine samples based on the isotopic ratios

Acknowledgments. This project is funded by the Ministry of Research and Innovation through Program 1 - Development of the National Research and Development System, Subprogram 1.2 - Institutional Performance - Projects for Financing the Excellence in CDI, Contract no. 37PFE/06.11.2018. Title of the project: "Increasing the institutional performance through consolidation and development of research directions within the USAMVCN".

\section{References}

1. Alkiș İM, Öz S, Atakol A, Yilmaz N, Anli RE, Atakol O (2014). Investigation of heavy metal concentration in some Turkish wines. Journal of Food Composition and Analysis, 33: 105-110.

2. Almeida CMS, Almeida AC, Godoy MLDP, Saint'Pierre TD, Godoy JM (2016). Differetiation among Brazilian wine regions based on lead isotopic data. Journal of the Brazilian Chemical Society, 27(6): 1026-1031.

3. Avram V, Voica C, Hosu A, Cimpoiu C, Măruțoiu C (2014). ICP-MS characterization of some Romanian white wines by their mineral content. Revue Roumanine de Chemistry 135(1): 1009-1019.

4. Barbaste M, Halicz L, Galy A, Medina B, Emteborg H, Adams FC, Lobinski R (2001). Evaluation of the accuracy of the determination of lead isotope ratios I wine by ICPMS using quadruple, multicollection magnetic sector and time of-flight analyzers. Talanta 54(2): 307-317.

5. Bora FD, Donici A, Rusu T, Bunea A, Popescu D, Bunea CI (2018). Elemental profile and ${ }^{207} \mathrm{~Pb} /{ }^{206} \mathrm{~Pb},{ }^{208} \mathrm{~Pb} /{ }^{206} \mathrm{~Pb}$, ${ }^{204} \mathrm{~Pb} /{ }^{206} \mathrm{~Pb},{ }^{87} \mathrm{Sr} /{ }^{86} \mathrm{Sr}$ isotope ratios as fingerprints for geographical traceability of Romanian wines. Notulae Botanicae Horti Agrobotanici Cluj-Napoca.

6. Chiodo LM, Covington C, Sokol RJ, Hannigan J H, Jannise J, Ager J, Greenwald M, Delaney-Black V (2007). Blood lead levels and specific attention effects in young children. Neurotoxicology and Teratology 29(5): 538-546.

7. Lichtfouse E, Schwarzbauer J, Didier R (2013). Pollutant diseases, remediation and recycling. (1th ed.). New York: Environmental Chemistry for a Suitainable World, (Chapter 8).

8. Liu D, Li Y, Ma J, Li C, Chen X (2016). Heavy metal pollution in urban soil from 1994 to 2012 in Kaifeng City, China. Water, Air, \& Soil Pollution 227(5): 154 DOI:10.1007/ s11270-016-2788-0.

9. Liu J, Wang D, Song B, Chen Z, Zhang X, Tang Y (2019). Source apportionment of $\mathrm{Pb}$ in a rice-soil system using field monitoring and isotope composition analysis. Journal of Geochemical Exploration 204: 83-89.

10. Martín JAR, Gutiérrez C, Escuer M, García-González MT, Campos-Herrera R, Águila N (2014). Effect of mine tailing on the spatial variability of soil nematodes from lead pollution in La Union (Spain). Science of the Total Environment 473-474: 518-529.

11. Mihaljevič M, Ettler V, Šebek O, Strnad L, Chrastný V (2006). Lead isotopic signatures of wine and vineyard soils-tracers of lead origin. Journal of Geochemical Exploration 88(1-3): 130-133.

12. Morrison RD (2000). Application of forensic techniques for age dating and source identification in environmental litigation. Environmental Forensics 1(3): 131-153.

13. Needleman H (2004). Lead poisoning. Medicine - Annual Review of Medicine 55: 209-222.

14. Nriagu JO (1983). Lead and lead poisoning in antiquity. Jhon Wiley \& Sons, New York.

15. O.I.V. (2016). Maximum acceptabile limits of various substances contained in wine. In Compendium of international methods of analysis of wine and must analysis. Paris, France. 